\title{
Kulturní výměna a zprostředkování obrazu Nového Zélandu. Fotografie českého geografa J. V. Daneše
}

\author{
Tomáš W. Pavlíček
}

DOI: 10.21104/CL.2017.4.05

Cultural exchange and transfer of ideas and images of New Zealand. Photographic pictures by the Czech geographer J. V. Daneš

Abstract The aim of this study is to present the journey of the Czech geographer Jiři Viktor Daneš (18801928) to New Zealand (1923), to explain the origin of his photographic collection and to postulate how Daneš presented his view of foreign cultures to Czech society both as a scientist and a former Czechoslovak consul in Sydney.

The analysis of pictures from the North and South Islands of New Zealand indicates that Daneš wanted to have his original visual take on geomorphology, nature, climate, society and culture of living. Based on his travel book Tři léta při Tichém oceáně [Three Years by the Pacific Ocean] (1926) it is possible to declare Daneš used photographic pictures as trails and sources for further scientific research and also for popularization. This study also clarifies the structure of this archival collection (positives, glass negatives and diapositives) and the extent of its damage during the floods of 2002. Using the archive classification and the method of cultural transfer, it was possible to restore the former photographic archives.
Tato studie vznikla na Akademii múzických umění v Praze v rámci projektu Zhodnocení a interpretace fotografického fondu Archivu Akademie věd ČR podpořeného z prostředků Institucionální podpory na dlouhodobý koncepční rozvoj výzkumné organizace, kterou poskytlo MŠMT v roce 2014. Projekt probíhá v letech 2014-2018 a na jeho řešení spolupracuje Katedra fotografie Filmové a televizní fakulty Akademie múzických umění v Praze, resp. obor Restaurování fotografie a Masarykův ústav a Archiv AV ČR, v. v. i.

Contact Dr. phil. Tomáš W. Pavlíček, Ph.D., Oddělení osobních a institucionálních fondů do r. 1952, Masarykův ústav a Archiv Akademie věd ČR, v. v. i., Gabčíkova 2362/10, 18200 Praha 8, Czech Republic; e-mail: pavlicek@mua.cas.cz.

Jak citovat / How to cite Pavlíček, Tomáš W. (2017.) Kulturní výměna a zprostředkování obrazu Nového Zélandu. Fotografie českého geografa J. V. Daneše. Český lid 104, 495-511. doi:http:// dx.doi.org/10.21104/CL.2017.4.05.

Keywords photography, photographic archives, journey around the world, cultural transfer, New Zealand, Maori culture, Jiří Viktor Daneš. 


\section{Motto}

„Novozéland'ané rádi ukazují na podstatné věcné rozdíly ve svém pojímání demokracie proti australskému vývoji tohoto směru a také geografické i podnebné poměry ostrovního dominia mají své nepopíratelné účinky na národní povahu, která v mnohém směru prý jest bližší anglické a skotské než australské."J. V. Daneš (Daneš 1926: 16)

\section{Úvod}

Výroky o kulturních rozdílech v mottu této studie napovídají, jakým způsobem jejich autor porovnával prostředí Nového Zélandu a Austrálie a zprostředkovával jejich obraz českému čtenáři. Je pochopitelné, že geograf vychovaný koncem 19. století odvozoval povahu národnostních skupin od přírodních podmínek jejich teritorií. Na svých výpravách do cizích krajin si český geograf Jiří Viktor Daneš chtěl osobně prohlédnout zajímavé geomorfologické útvary, jež znal z odborné literatury, a sledovat lokální životní podmínky a formy soužití mezi civilizovaným obyvatelstvem a původními, autochtonními kulturami. Od doby, kdy se v roce 1906 habilitoval na české Karlo-Ferdinandově univerzitě v oboru všeobecné geografie, nebyl jeho cílem úzce specializovaný průzkum a sběr geologických či antropologických vzorků v jedné lokalitě. Spíše chtěl získat obecnou představu o kulturních typech, klimatu a přírodních útvarech, aby je mohl porovnat s (cizojazyčnou) odbornou literaturou a aby pro české publikum vytvořil popularizační, ale vědecky fundovaný cestopis. Místo kompilace ze zahraniční literatury chtěl podat objektivní vědecký popis, kterým by revidoval naivní výklady a subjektivní dojmy cestovatelů - nadšenců. Zásadní roli v Danešově práci představovaly fotografie, které na cestách pořizoval, umožňovalo-li to počasí. Nebyly jen důkazem jeho návštěvy v popisovaných místech, ale představovaly vlastně pramenné stopy, které Daneš po návratu z cesty používal pro studium a psaní vědeckého textu. Kromě negativů a pozitivů nechával kolorovat skleněné diapozitivy, jež pak s oblibou využíval při univerzitních i popularizačních přednáškách. Charakter Danešova cestovatelství, fotografování a vědecké práce úzce souvisí s fenoménem zprostředkování vědění a kulturní výměnou.

Cílem předložené studie je sledovat Danešovu cestu po Novém Zélandu v době, kdy strávil „tři léta prri Tichém oceáně“ (1920-1923), a interpretovat obrazy ciziny zpř́stupňované slovem a fotografiemi, jimiž zprostředkoval přírodu a kulturu Nového Zélandu právě českému publiku. Tyto cíle otevírají řadu badatelských otázek, na něž nelze odpovědět v rozsahu jedné studie: Čemu Daneš věnoval ústřední pozornost a jak cestu připravoval? Jak strukturoval písemný a jak fotografický obraz cesty? Jakou míru pozornosti věnoval geomorfologii či fyzické geografii a kulturní antropologii či sociální geografii? Na tyto otázky navazuje téma kulturní výměny a vytváření obrazu cizího 
(Loewenstein 1997: 59-80; Kubiš 2003: 11-28). Jak hierarchizoval a hodnotil souvislosti a podobnosti mezi Novým Zélandem a Austrálií, mezi autochtonní kulturou a koloniální civilizací? Čeho si všímal z vlastního zájmu, čemu přikládal takový význam, aby se o něm dozvěděla právě česká veřejnost?

Druhý okruh se zabývá otázkou, jakým fotografem byl J. V. Daneš? Bylo by možné ze záběru jeho fotografií rekonstruovat motivy a témata, kterým přikládal váhu? Jakým zpo̊sobem dál nakládal s fotografickým obrazy, jak je reprodukoval a prezentoval odborné i laické veřejnosti? Pod pojmem fotografické obrazy rozumíme fotografické obrazové prameny, které je možné dále interpretovat jak v rovině zobrazení skutečnosti, tak v otázce zachycení obrazu a vyvolání jeho reprodukce na různých typech nosiče, které se při archivním zpracování souhrnně označují jako fotografické archiválie (Wittlich 2012: 108-110).

\section{Daneš jako typ vědeckého cestovatele}

Významný český geograf, cestovatel a diplomat Jiří Viktor Daneš (1880-1927) pocházel z Nového Dvora u Unhoště z rodiny velkostatkáře, záhy osiřel (dědické podíly $\mathrm{v}$ rodinném pivovaru mu umožňovaly cestovat) a svou matkou Johannou, roz. Fastrovou, byl vychováván k patriotismu a uváděn do kruhů české měštanské elity. Absolvoval dějepis a zeměpis na (české) filozofické fakultě v Praze (1898-1902), poté se habilitoval a v roce 1912 byl jmenován mimořádným, roku 1919 řádným profesorem. Díky četným předválečným exkurzím po Balkáně, cestě na Jávu a do Austrálie a účasti na několika vědeckých kongresech navázal řadu kontaktů se srbskými, německými i anglosaskými geografy a geology a získal mezinárodní uznání (např. 1910 byl zvolen dopisujícím členem Queenslandské královské akademie věd). Koncem roku 1919 byl jmenován prvním československým konzulem v Austrálii. Svou činnost v Sydney zahájil 6. 8. 1920, úřad formálně předal k 8. 1.1923 (Martínek 2017: $55-85,118,135)$. Cestu k protinožcům, exkurze podniknuté během konzulárního období a návrat do Československa shrnul v dvoudílném cestopise Tři léta při Tichém oceáně, jenž koncipoval jako cestu kolem světa. Druhý díl (Daneš 1926), zahrnující právě cestu po Novém Zélandu, věnoval své manželce Boženě (1893-1977), dceři literárního historika Josefa Hanuše, která Daneše na cestě doprovázela. Ta se také stala dědičkou a opatrovnicí jeho bohaté fotografické a dokumentární sbírky.

Za začátek Danešovy cesty kolem světa se považuje již odjezd z Prahy (květen 1920). Trasa vedla z Evropy přes Afriku a Asii do Austrálie, kde Daneš nastoupil jako generální konzul ČSR. Po skončení těchto povinností cestoval dále po Tichomoří, východní Asii a Severní Americe, odkud se vrátil zpátky do vlasti (v červenci 1923). Své poznatky, shromážděné dokumenty a fotografie zúročil v článcích a přednáškách na vysokých školách v Praze i Bratislavě. Svému celoživotnímu vědeckému tématu - krasovým jevům - se hodlal věnovat i na cestě 
do Spojených států amerických v roce 1927, kde měl na mnoha univerzitách domluvené také popularizační přednášky o Československu. Zde však tragicky zahynul pod koly automobilu, právě když se chystal fotografovat ropná pole na kalifornském pobřeží (Kodera 1998).

Jak známo, ještě před Danešem několik cestovatelů z českých zemí navštívilo Austrálii, Nový Zéland a další tropické ostrovy v Pacifiku. Tadeáš Haenke z Chřibské plul kolem Austrálie na začátku 19. století. První cestovatel z českých zemí, který podnikl cestu kolem světa, byl pražský Němec Franz Wilhelm Sieber. Posléze přes Austrálii cestovali Čeněk Paclt, Jan Jílek, jehož zpráva vyšla v roce 1841 v Květech, dále Alois Topič, František Čurda či Josef Polák, který se s bratry Forrestovými podílel na výzkumu Západní Austrálie, a konečně i profesor přírodopisu na smíchovském gymnáziu Josef Kořenský se svým přítelem, sládkem Karlem Řezníčkem. Kořenský pak na své druhé velké výpravě v letech 1900-1901 zamíril přímo na Nový Zéland, navštívil přístavy Dunedin, Christchurch, Auckland a ve Wellingtonu se chtěl setkat s malírem českého původu Bohumírem Lindauerem, který portrétoval domorodé Maory (Borovička 2010: 342-350, 381, 484; Todorovová 2011: 36-41).

Daneš se od cestovatelů „nadšenců“ odlišoval precizním vědeckým pozorováním geomorfologie terénu i antropologie kultury a osídlení. Tímto způsobem také strukturoval zmíněný cestopis. Obraz cizích krajů nevytvářel jen pomocí slov, ale také prostřednictvím fotografických obrazů. V jeho vědeckém zájmu bylo objektivním přístupem varovat české čtenáře před ukvapeným vystěhovalectvím (podobně varoval Baum 1939: 5-10, 16-18). V této souvislosti kritizoval porušování původních ekosystémů a nezodpovědný přenos (industriální) civilizace do tradičních kultur a přírody.

Ve svém cestopise ocenil zprávy a průzkumy především dvou tuzemských přírodovědců - Josefa Kořenského (1847-1938) a německého zoologa, pozdějšího profesora Německé univerzity v Praze Roberta Lendlmayra von Lendenfelda (1858-1913), který jako první vystoupil na Mt Kościuszko v Austrálii (1886) a věnoval pozornost charakteristickým znakům původní zvířeny na Novém Zélandu (Daneš 1926: 10). Rovněž navázal na zkušenosti z cesty na Jávu a do Austrálie, kterou společně s Karlem Dominem podnikli v roce 1909/1910 a shrnuli v cestopise Dvojím rájem (Daneš - Domin 1925).

\section{Fotografické obrazové prameny}

Dosavadní odborná literatura o Danešovi čerpala převážně z písemných pramenů (Čermák 1953; Hanták 2013; Kunský 1961: 280-300; Martínek 2008: 7175; Martínek - Martínek 1998: 99-106; Život a práce 1928: 129-228). Pokud však vyrovnáme fotografické obrazové prameny na stejnou úroveň vedle písemných pramenů a přiznáme jim možnost vypovídat o minulosti (byt jde spíše o stopy, indikátory), můžeme se pokusit o interpretaci minulosti v různých rovinách. „Co je považováno za historický pramen, je totiž zásadně závislé 
na mocenském řádu nejen v minulosti, kdy dokument vznikl a byl předáván, ale i v současnosti, kdy je uchováván a zpřístupňován $\mathrm{v}$ archivech a knihovnách.“ (Horský 2014: 19)

Záběr studie je zúžen na vybranou část Danešovy cesty kolem světa, zachycenou v cestopise Tři léta při Tichém oceáně a na dochované fotografické archiválie uložené v osobním fondu J. V. Daneše v Archivu AV ČR. ${ }^{1}$

Vybraný novozélandský úsek z Danešovy cesty kolem světa a k němu dochované fotografické snímky představují dostatečně reprezentativní celek, který má pestrý obsah záběrů (geografické, etnografické a turistické cíle) a zahrnuje různě dochované, částečně poškozené fotografie vytvořené různými fotografickými procesy a technikami - fotografické desky (skleněné negativy a diapozitivy) a fotografie na papírové podložce: pozitivy a pohlednice (Pavlíček - Tomsová 2016). V průběhu cesty po Novém Zélandu Daneš sám zhotovil téměř 150 záběrů. Pokud pro nepřízeň počasí nebo kvůli nedostat$\mathrm{ku}$ času nemohl fotografovat, snažil se v dané lokalitě zakoupit tematické pohlednice. Podle soupisu, který v šedesátých letech 20. století pořídila Božena Danešová při předávání (prodeji) části fotosbírky do Ústředního archivu ČSAV, novozélandský soubor obsahoval 122 negativů, 135 diapozitivů (z toho 131 kolorovaných) a 190 pozitivů (z toho řadu pohlednic, 4 tisky a 2 mapy). ${ }^{2}$ Tento soupis představoval dostatečnou pomůcku pro základní orientaci ve fotosbírce. Proto když byl archivní fond J. V. Daneše v roce 1996 zpracován na úrovni inventárního soupisu, vyčlenily se soubory skleněných fotografií a byly uloženy spolu s dalšími fotografiemi ve zvláštní místnosti. Kdo mohl tušit, že právě tam budou fotosbírky poškozeny povodní?

\section{Poškození fotografických archiválií}

Povodně v roce 2002 zasáhly 14. srpna také Archiv AV ČR (nacházející se tehdy v Praze v Bohnicích) a nastartovaly události, jež vedly k zásadnímu poškození a destrukci struktury archivních souborů v Danešově fotosbírce. Vyklízení zatopených depozitáŕů mohlo začít teprve 17. srpna po opadnutí vody. Voda poškodila fotografické archiválie mechanicky, chemicky i biologicky (nánosy bahna, plísně). Čištění archiválií bylo prováděno podle doporučení tehdejšího Státního ústředního archivu (dnes Národního archivu) čistou vodou s př́ípadným přídavkem Ajatinu (Borýsková - Mádlová - Pavlíček 2014).

1 Masarykův ústav a Archiv Akademie věd České republiky, v. v. i., Praha, Archiv AV ČR (dále: A AV ČR), fond Daneš Jiří Viktor (dále: fond J. V. Daneš), k. 7-9; kromě toho jde o výběr z neuspořádané části osobního fondu, který navíc byl v roce 2002 částečně zasažen povodní. Další rozsáhlé části Danešových egodokumentů, fotografií a sbírek se nacházejí v Náprstkově muzeu, v Národním muzeu a ve Sládečkově vlastivědném muzeu v Kladně.

2 A AV ČR, fond J. V. Daneš, k. 10 - strojopisné seznamy fotografických souborů. Originál strojopisných seznamů byl prostudován v Danešově fondu v Sládečkově vlastivědném muzeu v Kladně. 
Poškozeným fotografiím byla věnována pozornost při řešení stávajícího projektu, který se soustředil nejen na obsahový popis fotografií, ale také na jejich fyzickou stránku, například míru poškození a rozměry. Skleněné negativy jsou nejčastěji ve stereo provedení ve formátu $9 \times 18 \mathrm{~cm}$, diapozitivy ve čtvercovém provedení $8,5 \times 8,5 \mathrm{~cm}$. Fotografie na papírové podložce se objevují ve velmi různých velikostech; nejčastější formát pozitivních snímků je 10,5 × $14 \mathrm{~cm}$. Nechybějí ovšem ani výrazně větší pozitivy adjustované na tvrdém kartonu formátu A4. Skleněné fotografické desky ze Severního ostrova Nového Zélandu vykazují výrazné poškození vodou, lokálně vedoucí až k rozpadu želatinové citlivé vrstvy, čímž někdy došlo ke ztrátě obrazu. Takové fotografie zůstávají v neuspořádané části archivního fondu. Kolorované diapozitivy vykazují různou úroveň odbarvení. Některé mají odplavený barevný pigment jen v okrajích diapozitivu. Poškozená skleněná podložka je u většiny negativů i diapozitivů s různou úrovní znečištění. Na negativech jsou zbytky uschlých kapek a krystalky nečistot (Pavlíček Tomsová 2016: 72).

K mechanickému poškození negativů i diapozitivů došlo ovšem i v případě fotografií z Jižního ostrova a v případě obou souborů zakoupených dokumentačních pohlednic a pozitivů, které voda nezasáhla. Fotografie na papírové podložce byly totiž zpracovány a uloženy v kartonech se spisy. Jaký postup se nabízí při zpracovávání Danešovy sbírky? Restaurování poškozených fotografií přichází v úvahu jen ve zvlášt vybraných případech. Primárním stupněm konzervace celé fotosbírky je přebalení fotografií do obálek z nekyselého papíru, vytřídění fotografií se zcela smytým, neidentifikovatelným obrazem, archivní třídění, katalogizace a skenování určených archiválií. Při poslední archivní manipulaci se podařilo nalézt a znovu určit 33 negativů a 41 původně kolorovaných diapozitivů). Čtyři novozélandské soubory tak aktuálně tvoří 258 záběrů, a pokud provedeme evidenci fotografických archiválií podle typu podložky, jedná se celkově o 390 fotografií. Výsledný obraz cesty po Novém Zélandu se tedy skládá z různých druhů fotografií a místy je značně fragmentární. ${ }^{3}$

\section{Kulturní výměna}

„Napínalo nás rozpoznati, jaké rozdíly vytvořily se mezi obyvatelstvem Austrálie a Nového Zélandu."J. V. Daneš (Daneš 1926: 14) 
Fenomén zprostředkování obrazů a vědění budí zdánlivě dojem jednostranného procesu, nicméně jde o interkulturní stř̌etávání, o snahu inspirovat či identifikovat čtenáře s názory nebo praktikami kultury, jejíž obraz autor zprostředkovává (Kreuzzieger 2015: 110-119). Tento přístup má tedy komparativní i bilaterální rozměr a chce studovat: 1) kulturní podmínky a kontexty, v nichž Danešovy fotografie i cestopis vznikaly, 2) místa produkce vědění, která se podílela na Danešových závěrech, a konečně 3) životní svět vědce a jeho komunikaci. Metodické postupy se opírají o antropologické směry kulturních dějin vědy a vědění (Latour 1993).

Na Danešově přístupu je zajímavá okolnost, že místem produkce jeho vědění nebyla pouze knihovna či terénní výzkum, ale kombinace podrobně prostudované literatury s pozorováním geomorfologických tvarů, klimatu a kulturních praktik in situ a jejich fotografováním. Meziprostorem pro zpracování nasbíraných pramenů byla fotokomora, přípravy na dílčí přednášky a kolorování vybraných diapozitivů. Psaní cestopisu navíc obohatily vlastní dojmy (oživené fotografiemi) a poznámky z cestovního deníku. Ten sice nebyl nalezen, ale sám Daneš se o něm zmiňuje.

Za kulturní transfer lze považovat neorganizovaný přenos či jednostrannou výměnu kulturních praktik, návyků a technických dovedností cizího prostředí, bez ohledu na kulturní kontext autochtonní kultury. Sám Daneš však vysvětloval specifika novozélandské kultury geologicky odlišnou historií a na ní závislými př́rodními i kulturními podmínkami. Oboustrannost kulturní výměny podtrhl lichotivými zprávami na adresu nové Československé republiky a zájmem novozélandských, následně britských obchodních kruhů o její stabilní národohospodářské postavení a technicky zdatné a solidní výrobce (Daneš 1926: 16).

\section{Průběh cesty po Novém Zélandu}

Danešova mise konzula v Sydney skončila počátkem roku 1923 a 6. ledna 1923 se manželé vydali na zpáteční cestu. Daneš ji naplánoval jako badatelsko-turistickou expedici. Do přístavu přišlo velké množství lidí - Australanů, krajanů i Jihoslovanů, aby se rozloučili s československým diplomatem a jeho chotí, což dokládá způsob házení „papírových serpentin“ přes lodní palubu (Daneš 1926: 1). Když se lod' odtrhla od mola, přetrhaly se papírové stužky, čímž se lidé na hrázi symbolicky rozloučili s př́teli na palubě. Prvním cílem cesty se stal Nový Zéland. Vhodnou okolností k návštěvě souostroví bylo konání XVI. sjezdu Australského svazu pro vědecký pokrok ve Wellingtonu, kam byl Daneš pozván přednášet. Generální sekretář svazu geolog Ernest Clayton Andrews (1870-1948) jej kooptoval do kongresového výboru. Kromě dvou odborných exposé přednesl Daneš rovněž velkou přednášku O krajinných typech severního Queenslandu, kterou připravil „se světelnými obrazy“. Využití vlastních kolorovaných diapozitivů pro vědeckou práci tehdy uplatňovali také další vědci, 
na něž se Daneš v cestopise odvolává. Kromě Andrewse, který dříve vedl i výpravu na Fidži a Tongu, to byl sir Douglas Mawson (1882-1958), jenž provedl několik antarktických expedic.

Nový Zéland Daneše zaujal již dříve svou polohou, rozmanitostí podnebí a odlišným geologickým základem. Upozorňoval čtenáře, aby nepřenášeli svůj dojem z Australských Alp na Novozélandské Alpy, které se až na pojmenování svým původem zcela odlišují. Vlastními fotografiemi dokumentoval, jak vysoké horské štíty a ledovce přecházejí v jezera a zvláštní fjordy - na jedné straně řeky prales, na druhé straně holé morény. Ostrovy byly izolovány už v pleistocénu, což Daneš hned v úvodu první kapitoly dokládá fotografií a zmínkou o fosilních zbytcích ptáků běžců z rodu Moa.

Po prostudování vícerých snímků je patrné, že Daneš nebyl nadprůměrným fotografem. Spíše vytvářel dokumentační sbírku vhodnou pro přednášky a publikace. Jak vlastně postupoval při třídění pořízených fotografií? Většinou chronologicky podle průběhu cesty, ale například při třídění novozélandských snímků zařadil na začátek celého souboru dvě mapy a dvě reprodukce ptáků Moa a Kiwi (č. 412/3, 412/4). Za hlavního aktéra geologických změn a střídání krajinných typů Severního ostrova Daneš označuje sopečné jevy (gejzíry - 24 fotografií), na Jižním ostrově zase ledovcová jezera, fjordy a strmé štíty Novozélanských Alp (21 fotografií). Podobně se chystal prostudovat domorodé Maory, „kteří ovšem v dnešním stavu svého přizpůsobení se ke kultuře bělošské nejsou již ani nebezpeční ani tak zajímaví jako před léty“ (Daneš 1926: 14). Zároveň sledoval kulturu života „bílého obyvatelstva“. Těmto zájmům odpovídal také průběh celé cesty po Novém Zélandu a tropických ostrovech Pacifiku.

V průběhu novozélandského kongresu Daneš využil příležitost seznámit se s urbanisticky promyšleným řešením Wellingtonu umístěného v komplikovaném terénu, zhlédnout relikt původního pralesa u řeky Wainuiomaty a zúčastnit se exkurze do provincie Taranaki, kde zachytil kužel stejnojmenné sopky (vrchol Mt Egmont). Při návštěvě New Plymouthu byl překvapen moderní technizací města a zároveň zachovanou přírodou na jeho okraji (houštiny kaprad'ovitých stromů). Tento fakt dokládá, že si kladl otázku ochrany přírody před rozšiřujícím se osídlením.

\section{Exkurze po Jižním ostrově}

První kongresová exkurze zamírila do Nelsonu na ledovec přejmenovaný na počest císaře Františka Josefa, který jej osobně v roce 1865 navštívil (Daneš si pořídil alespoň pohlednici). Zatím se druhá skupina včetně manželů Danešových přesunula na Jižní ostrov do okolí průmyslového města Christchurch. Daneš vyzdvihl vodní elektrárny na nedalekém jezeře Coleridge, ale upozornil na kácení a požáry pralesů pod Novozélandskými Alpami. Po týdnu stráveném v hotelu Hermitage se vypravili autobusy do oblasti obtížně 
přístupných ledovcových jezer Tekapo, Pukaki, Wakatipu, Manapouri a Te Anau. S jednou skupinou turistů podnikli výstup k Punčochovému ledovci, nicméně špatné počasí jim zabránilo v další alpinistice. Její historii Daneš načrtl alespoň písemně a při té př́ležitosti připomněl řadu výstupů, které zde podnikl zmíněný zoolog Robert von Lendenfeld nebo také Josef Kořenský (Kořenský 1903: 37-50).

V Queenstownu u jezera Wakatipu Daneš prvně v životě zažil 8. února 1923 malé zemětřesení. Projíždky po jednotlivých jezerech a v údolí řek jsou v cestopise popsány velmi podrobně, nepochybně na základě vlastních fotografických obrazů (celkem 15 ks). Exkurzi po jezeře Manapouri dokumentoval čtyřmi fotografiemi. Na kolorovaném diapozitivu „Jezero Manapouri“ (č. 414/11, 8,5 × 8,5 cm) vidíme Boženu Danešovou sedící na kamenech na břehu jezera. Hlavní záběr fotoaparátu je však zaměřen na hladinu jezera, zalesněný protější břeh a hory tyčící se vysoko nad jezerem. Zdařilejší snímky s pózující manželkou na skalisku s vlnami mořského příboje pocházejí z expedic po Austrálii. Avšak tento fotografický obraz posloužil Danešovi jako pramen při psaní cestopisu. Díky němu si připomněl situaci i kontext, přestože samotná fotografie ještě neumožňuje rozpoznat, že „fjord vniká daleko mezi hory, vždy znovu a znovu si otvírajíc [sic] průchod mezi zdánlivě nepřerušenými horskými srázy“ (Daneš 1926: 108). Od jejich temnějšího pozadí se v popředí odráží skalní štít, který je dokumentem činnosti ledovců - „klínovitý štít zvaný Monument, jehož charakteristický tvar byl vymodelován ledovci, které jeho boky důkladně kdysi obrousily“ (Daneš 1926: 106). O jeho zachycení šlo autorovi především. K morfologicky významnému místu se cestovateli podařilo přibližit ještě na motorovém člunu a zobrazit ho z klidnější zátoky „při výtoku řeky Waiau z jezera Manapouri“ (č. 414/12). U tohoto snímku si Daneš dal záležet na kompozici. Ledovcem obroušený štít Monument, nehybně stojící v dálce, kontrastuje s hladinou vody, která zbyla po ledovci. Aktivní roli vody zvýrazňuje člun odplouvající ve směru od mužské postavy, která jakoby celý děj fotografuje. Postava situaci nejen oživuje, ale ukazuje reálné měřítko prrírodních útvarů. Jde-li o Daneše, mohl cestovatel o stisk spouště požádat manželku. Občas sice využíval i samospoušt', ale po kamenitém břehu jezera by sotva dovedl tak rychle zaujmout pozici. Moment zachycený na fotografii sice není načasován vhodně, nebot člun už stihl odplout z centrálního místa obrazu, ale výsledná kompozice vyznívá přesvědčivě. Muž na snímku vědecky dokumentuje geomorfologii ledovcových jezer a štítů.

Na pěší túře k největšímu fjordu Milford Sound vznikl také záběr nazvaný „V horském lese pod sedlem Mac Kinnonovým“ (č. 414/26). Místy vedla cesta korytem potoka a přes mokré kapradiny, než výprava dosáhla zmíněného lesa. Daneš nelitoval času na fotografování a vnímání detailů zvláštního horského porostu: „Ani jsme nepospíchali, nebot' lesní stezka měla tolik podivného půvabu, že rádi jsme se zastavovali a prohlíželi si dopodrobna rozkošná zákoutí a těšili se výhledy do houštin, kde tisíce vodních kapek visících na bradatých 
lišejnících lesklo se jako perličky.“ (Daneš 1926: 123) Z Danešovy fotografie jsou patrné nízké, rozvětvené buky ověšené lišejníky a na zemi houšt kapradin. Díky kolorování působí jinak ztemnělý obraz diapozitivu tajuplně. Jak uvádí cestopis o dvě strany dále, Danešovi zůstávali většinou poslední, protože většina členů výpravy se hnala dopředu, jako by šlo o sportovní výkon (Daneš 1926: 125).

Od posledního jezera Te Anau podnikli sedmidenní pěší túru údolím řeky Clinton k fjordu Milford Sound kolem imponujícího vysokého Sutherlandova vodopádu, který objížděli na lod'ce (fotografie č. 20-45). Fjord je „dokumentem ledovcové činnosti“ (Daneš 1926: 133) a jako takový ho český geograf studoval a fotografoval (č. 27-45). Poslední exkurzi na Jižním ostrově podnikl do oblasti Southlandu a provincie Otago. Při návštěvě obou velkých měst - Invercargillu a Dunedinu - si všímal jejich kulturní úrovně (způsobené mj. lokální skotskou svobodnou presbyteriánskou církví, která se oddělila od většinové) a technicky vybavených farem (umělé zavlažování). Zmínil také dřívější zlatokopeckou horečku, o níž psal již Čeněk Paclt (1954: 113-123).

\section{Exkurze po Severním ostrově}

Po čtyřech týdnech strávených na Jižním ostrově se Danešovi vrátili do Wellingtonu, odkud se vypravili poštovním automobilem na průzkum hor, vulkánů a gejzírů v okolí Wairakei. Cesta k jezeru Taupo českého geografa trocha zklamala, protože neviděl nic ze sopečné činnosti, ale náhradou za to mu byl silný dojem z gejzírů na Bílých a Růžových terasách mezi osadami Whakarewarewa, Rotorua a Ohinemutu. Daneš poukázal na rychlost, s jakou vegetace pokrývá drobnou popelavou lávu.

Lázeňské město Ohinemutu na břehu jezera Rotorua představuje seizmicky nejklidnější oblast. Místní Maory Daneš užil jako př́́klad kulturní akomodace: přizpůsobili se moderní civilizaci stylem oblékání a bydlení, a přitom se nevzdali tradičních obyčejů a rituálů. Rákosové chýše vyměnili za evropský typ domu whare, který v maorských vesnicích dříve sloužil jako společný dům celé komunity. V době Danešovy návštěvy sem putovalo mnoho Maorů, aby vykonali tradiční obřady za zemřelého předáka. Maorové, oblečeni sice po evropsku, pojímali nadále rituály jako posvátné, a proto nevpouštěli žádné návštěvníky dovnitřr. Před samotným whare probíhala část obřadů a tanců, než bylo tělo nebožtíka přeneseno do kostela k provedení křestanských obřadů. Maory hodně popouzelo, když se běloši jejich rituálům divili či posmívali (Daneš 1926: 193-197). Z tohoto důvodu museli turisté zůstat opodál budovy a možná proto Daneš nepořídil více než dva snímky přímo před whare. Pozoruhodný je v tomto ohledu dosud nereprodukovaný negativ „Whare v Ohinemutu, jiný záběr“ (č. 412/60), který ukazuje, jak toho dne „bylo tu a na celé návsi velmi živo. Stále přicházeli noví soukmenovci z okolních vesnic a obřadné vítání nemělo konce. Muži i ženy podávali si ruce a s velikou vážností vykonávali 
starodávný obřadný pozdrav tisknouce nos na nos. Není to tření nosů, jak se obyčejně ř́kává, nýbrž pomalé a důstojné přitlačení jich k sobě. Největší pozornosti těšila se vdova po zemřelém, statná to žena prostředních let oblečená do černého evropského oděvu“ (Daneš 1926: 194). Na snímku je ve skupince žen před vchodem do whare, dále díky stereo formátu vidíme 23 evropsky oblečených postav včetně dětí (málokdo prý přišel v tradičním maorském ceremoniálním kroji). Rovněž si můžeme všimnout, že budova whare je už napojena na elektrické vedení. Protože Daneš zaznamenal jisté znepokojení domorodců z turistických návštěvníků, vzdal se pokusu dostat se dovnitř whare a obraz zachytil z větší vzdálenosti od domu než předchozí snímek (srov. vodou poškozený diapozitiv č. 412/59). Detailní záběr obřadného pozdravu s přitlačováním nosů pak v cestopise doplnil reprodukcí zakoupené pohlednice (Daneš 1926: 169).

Další den byla naplánována výprava na gejzírové tůně ve Whakarewarewě. Obohacující byly výklady maorské průvodkyně, která bezvadnou angličtinou poukazovala na současnou tendenci Maorů zahálet a spoléhat se na peníze od turistů. Poslední expedice přivedla Danešovy do Aucklandu. Geografovi se líbil pohled na př́stav se skvělou polohou, ale podivil se, proč ani jeden z městských parků nebyl založen jako ochranné pásmo pro udržení původního rázu kraje. Zbytky původních lesů s gigantickými stromy zhlédl na výletě do pohoří Waitakerei Range.

Do fotografického souboru Severního ostrova Daneš zařadil i reprodukce několika cizích fotografií Maorů, jejich obydlí (whare), řezeb a bran. Způsob vytváření reprodukce z pohlednice adjustované pomocí napínáčků je dobře patrný na vodou poškozeném diapozitivu č. 412/62 „Brána maorského Pah“. Kmenové pah se nacházelo v př́íhodné poloze při horním okraji gejzírových teras a tvořilo obranou pevnůstku proti nočním přepadením. Řezby jsou typicky maorské, velmi impresivní, s rysy fantastických oblud. Zařazením pohlednic z produkce novozélandských fotoateliérů Daneš (nevědomky) zprostředkovával tyto aranžované obrazy maorské kultury vedle svých vlastních dokumentárních fotek. Tímto zjištěním se dostáváme k otázce kulturního transferu.

\section{Hodnocení kulturního přenosu a výměny}

Vedle dokumentů ledovcové činnosti (řeky, jezera, fjordy) studoval Daneš vliv klimatu na osídlení a formování lidské kultury. Šlo mu jednak o životní podmínky soudobých Novozéland'anů, jednak o kulturu původních maorských obyvatel. Podle něj byli Maoři již př́liš akomodováni k bělošské kultuře, než aby byli pro studium zajímaví (Daneš 1926: 14). Informuje ještě o poslední velké maorské válce s bělochy v závěru sedmdesátých let 19. století, kanibalismu a o maorském království, do něhož se kmeny v roce 1858 sjednotily a zvolily jednoho náčelníka králem. Tento kulturní transfer z nouze však 
neměl trvání, pro vnitřní neshody Maoři nedovedli konkurovat bílému obyvatelstvu (Paclt 1954: 120-123).

Násilné činy Maorů se Daneš snaží zasadit do kontextu tak, aby vynikly přehmaty dobrodruhů - odtud pramenily pravé důvody odporu vůči kolonizátorům. „Maoři na Waikati nebyli zásadními nepřáteli bělochů vůbec, ale př́áli si míti plnou moc, nepouštěti mezi sebe škodlivých a bezohledných kolonistů a podržeti plnou samosprávu pod vrchní mocí britské koruny.“ (Daneš 1926: 168)

Zaangažování Maorů v kácení lesů Daneš chápe jako důsledek kulturního transferu.

Naopak jako pozitivní kulturní výměnu lze označit obrazy Gottfrieda Lindauera (1839-1926), jehož portréty a scény z maorského života Danešovi zhlédli v místní galerii (Filip - Musil 2015). Daneš velmi litoval, že kvůli zpoždění nemohli stařičkého malíře navštívit na jeho venkovském statečku. Zároveň poznamenal, že cena jeho obrazů poroste vymíráním Maorů. Malíre pocházejícího z německojazyčné rodiny označil jednoznačně jako „našeho krajana“. V něm dal český národ Novému Zélandu umělce, jehož obrazy obohatily zase české prostředí - ze dvou zmíněných obrazů ve vlastnictví Václava Friče přetiskl reprodukci „Maorské ženy s dítětem“ (Daneš 1926: 212).

Tento kolorovaný diapozitiv (č. 412/54) zachycuje jednu z třiceti verzí malírových portrétů Any Rupenové, správně Heeni Hirini, z kmene Ngāti Maru, s níž se Lindauer setkal v roce 1878 za svého pobytu na poloostrově Coromandel (reprodukci viz Filip - Musil 2015: 177). Právě tento olej na plátně získal zlatou medaili na světové výstavě v Saint Louis v roce 1904. Místo malíře však větší úspěch slavil Lindauerův mecenáš Henry Partridge (1848-1931), v jehož Lindauer Gallery v Auckalndu byl obraz k vidění od roku 1901. Ani potomci Any Rupenové nevěděli, jak extenzivně byl portrét jejich (pra)matky distribuován. Už na začátku 20. století byl soubor Lindauerových obrazů vnímán jako součást (novodobé) domácí maorské kultury. Lindauer se sice snažil o věrnost, ale jednotlivé prvky překombinoval, upravoval tetování apod. Obrazy odkazují sice na „interkulturní stř̌etávání mezi evropskými koloniálními zájmy a zájmy Maorů“, ale nejedná se o jejich věrnou dokumentaci, spíše o „interpretační perspektivy a evropské představy o nich“(Kreuzzieger 2015: 119, 123). Daneš, poměrně citlivý na zachovávání původních kultur, se paradoxně podílel na „globalizaci“ obrazu a nikde neuvádí jméno portrétované ženy (Daneš 1926: 195).

Z časových důvodů Danešovi nestihli navštívit ani původem českou osadu Puhoi, která prý byla již značně asimilovaná. Německojazyční kolonisté pocházející z okolí Stodu u Plzně vyrazili v roce 1863 s požehnáním kardinála Schwarzenberga hledat svobodnou půdu na Novém Zélandu (Heller 2005: 7-36). Jako důležité zjištění z hlediska tématu této studie se ukazují poválečné postoje českého geografa. Konzul Daneš - oficiální reprezentant československého státu - identifikuje malíře Lindauera s českým národem. Rovněž při hodnocení tzv. Bohemians z vesnice Puhoi dává najevo, že za národní (už) 
nepovažuje české nacionální faktory (jazykově politické), ale kulturně české faktory. Lidská kultura je však v Danešově pojetí dána př́rodními podmínkami, a ty byly pro Čechy a české Němce geograficky stejné.

\section{Závěr. Fotografie jako obrazový pramen}

Při posuzování vlivu přírodních podmínek na osídlení - domorodé i bělošské - Daneš zdůrazňoval specifika „malého státu“ - na Austrálii nezávislého dominia, za něž byl Nový Zéland prohlášen v roce 1907. Lidé z Nového Zélandu rádi zdůrazňovali, čím se liší od Australanů, mj. také pojetím demokracie (Daneš 1926: 16). Odvolávali se přitom na průběh osidlování ostrovů, na nichž od počátku vznikala netrestanecká kolonie. V době strávené na československém generálním konzulátu v Austrálii Daneš registroval velké množství poptávek novozélandských firem po československém zboží (Daneš 1926: 35). Obecně byl více vítán dovoz ze zemí z okruhu států Dohody než z Německa, Rakouska apod.

Na první pohled měl Nový Zéland mnoho společných rysů s Austrálií, ale historicky poučený badatel dovedl vysvětlit přičiny klidnějšího vývoje, v němž se občané po období válek s Maory rozhodli pro federální parlamentní soustavu. Především zásluhou guvernéra Sira George Greye se podařilo Maory pacifikovat a vyjít vstř́í jejich skutečným potřebám (Daneš 1926: 230). Hospodářský rozmach sedmdesátých let 19. století se po recesi následujícího desetiletí podařilo rozehnat, když se k vládě dostala znovu liberální strana, která zároveň vyšla vstřric požadavkům dělnictva (sociální zákonodárství). Ve srovnání s dominantní Austrálií vychází vývoj na Novém Zélandu i přes strasti první světové války takřka idealisticky. Některá Danešova hodnocení a charakteristiky Nového Zélandu je třeba považovat za obecné kulturní stereotypy (protinožci apod.). Nalezli bychom je rovněž v dílech jiných evropských cestovatelů, a to dokonce i v mladším období (Beekman 1983: 255-350). Svědčí to však spíše o stereotypně vyhledávaných turistických cílech a tématech.

Daneš, který bývá v literatuře označován za republikána a politického sympatizanta agrárníků (Martínek 2017: 219), nicméně za důležitější než domácí politickou scénu považoval osudy krajanů (případně Jihoslovanů) v zahraničí. Šlo mu o obraz československého státu a výměnu obchodních kontaktů, a v tom byla kulturní výměna mezi dvěma menšími zeměmi Československo Nový Zéland výhodou. $\mathrm{V}$ tomto směru by bylo vhodné porovnat novozélandský příklad s jinými minoritními kulturami, jimiž se Daneš také zabýval (Ainové v Japonsku, indiánské kultury v USA apod.). Dále je možné se ptát, jak Danešovi vrstevníci a kolegové (např. Karel Domin, Viktor Dvorský aj.) používali fotografie ve vlastní vědecké práci a jak hodnotili procesy kulturní výměny a souvislosti mezi př́rodními podmínkami a kulturou (podobně Latour 1993: 102). Konkrétně Nový Zéland navštívili v meziválečném období další československé expedice (např. Jiří Baum v roce 1935). 
Formální a obsahová analýza vybraných fotografických archiválií J. V. Daneše vedla ke zjištění, jakým způsobem jako vědec pořizoval fotografie a jak je dále ve své práci využíval.

Na základě svých očekávání, studia a detailní př́ípravy jednotlivých exkurzí se přímo v terénu rozhodoval, které objekty bude fotografovat. Jim posléze přikládal mimořádnou důležitost při psaní vědeckých prací či cestopisu. Pohlednice lokálních ateliérů kupoval, když bylo nepříznivé počasí nebo pokud se mu zdálo nevhodné zblízka dokumentovat aktuální situaci například v domorodé vesnici (viz Maoři scházející se k obřadům za zemřelého předáka).

Po roztř́iění obsahů fotografií na základě analýzy všech čtyř novozélandských souborů vyplývá, že Daneš upřednostňoval záběry z oblasti fyzické geografie (geomorfologie krajiny, sopky, jezera, ledovce - 205 záběrů) a antropogeografie (domorodé kultury a etnografie - 25 záběrů) před jednoznačně turistickými cíli a urbánním osídlením (26 záběrů); zbývající 2 fotografie se týkaly prrímo vědeckého kongresu.

Při prohlížení negativních obrazů se rozhodoval, které snímky vyřadí jako nezdařilé či rozmazané, které pohlednice přefotografuje na skleněnou podložku, jaké diapozitivy nechá kolorovat a které záběry použije pro knižní reprodukce (často se shodují s fotografiemi na papírové podložce). Diapozitivy sloužily jako „světelné obrazy“ pro univerzitní i popularizační přednášky. V tomto ohledu se snažil držet krok se zahraničními kolegy; v případě novozélandských vědců lze poukázat, že ho inspirovalo také používání filmových sekvencí. K této činnosti se však již nestačil dostat. Před kolorováním diapozitivů Daneš na základě své paměti a zkušeností instruoval výtvarníka $\mathrm{k}$ volbě barev pro jednotlivé části obrazu.

Svoje vidění světa (obraz cizí kultury) konstruoval také písemně. Z cestopisu je patrná jedinečná role fotografických archiválií jako prostředku napomáhajícím psát cestopis - rozpomenout se na detaily zažitých situací a posléze konkretizovat vědecký popis př́rodního objektu či určitého jevu. Fotografie tedy rozhodně nelze chápat jako pouhé ilustrace geografického či etnografického popisu. Projíždky po jednotlivých jezerech a v údolí řek jsou v cestopise popsány na základě vlastních snímků.

Daneš sice nepostřehl, že při pozorování maorské kultury se už setkává s jejím upraveným obrazem, nicméně citlivě rozlišuje původní prvky od zásahů způsobených koloniálními velmocemi. Zároveň však Daneš význam fotografie překonává, a to dvojím způsobem: 1) snímky podle něj zkreslují, zploštují horizontální obraz a dojem z krajiny, 2) s odstupem času při psaní cestopisu stále více přesouvá svou pozornost $\mathrm{z}$ geomorfologického k antropogeografickému a etnografickému zaměření. Posun od fyzické k sociální geografii a antropologii je patrný i z témat univerzitních přednášek v závěru života. Fotografie (ve svém trojím technickém provedení: negativy, diapozitivy a pozitivy) se tedy staly spoluaktérem v procesu kulturní výměny. 


\section{Seznam pramenů a literatury}

Masarykův ústav a Archiv Akademie věd České republiky, v. v. i., fond Daneš jiří Viktor, inv. č. 412-415.

Baum, Jiří. 1939. Na daleké cesty. Praha: Vesmír.

Beekman, Vladimir. 1983. Cesty k protinožcům. Praha: Panorama.

Borovička, Michael. 2010. Velké dějiny zemí Koruny české. Tematická rada. Cestovatelství. Praha - Litomyšl: Paseka.

Borýsková, Štěpánka - Mádlová, Vlasta - Pavlíček, Tomáš W. 2014. Fotografické archiválie ve fondech Archivu AV ČR dvanáct let po povodni. Práce z dějin Akademie věd 6: 2: 180-208.

Čermák, Jiří. 1953. Prof. dr Jiří Daneš. Sborník Československé společnosti zeměpisné 58: 3: 129-137.

Daneš, Jiří Viktor - Domin, Karel. 1925. Dvojím rájem. Praha: Nakladatelství J. Otto.

Daneš, Jiří Viktor. 1926. Tři léta při Tichém oceáně. II. Praha: František Borový.

Filip, Aleš - Musil, Roman. 2015. Gottfried Lindauer. 1839-1926. Plzeňský malír novozélandských Maorů. Řevnice: Arbor vitae.

Hanták, Daniel. 2013. Jiří Viktor Daneš (1880-1928). Bakalářská práce. Praha: PedF UK. Heller, Wilfried. 2005. Die „Bohemians“ in Neuseeland - eine ethnische Gruppe? In: Mitteilungen der Österreichischen Geographischen Gesellschaft 147: 7-36.

Horský, Jan. 2014. Pramen. In: Storchová, Lucie a kol. Koncepty a dějiny. Proměny pojmů v současné historické vědě. Dolní Břežany: Scriptorium: 19.

Kodera, Pavel. 1998. Jiří V. Daneš. Akademický bulletin 1: 4.

Kořenský, Josef. 1903. K protinožcům: cesta do Australie, Tasmanie, na Nový Zeland, Ostrovy Přátelské, Samojské a Vitijské a návrat Celebesem, Javou, Korálovým mořem, Siamem, Čínou, Žaponskem, Koreou a Sibiří. [Díl 2]. Praha: Otto.

Kreuzzieger, Milan. 2015. Vizuální kultura a interkulturní střetávání. Gottfried Lindauer mezi Maory a kolonizátory. In: Filip, Aleš - Musil, Roman. 2015. Gottfried Lindauer. 1839-1926. Plzeňský malî́r novozélandských Maorů. Řevnice: Arbor vitae: 110-129.

Kubiš, Karel (ed.). 2003. Obraz druhého v historické perspektivě. II. Identity a stereotypy při formování moderní společnosti. Praha: Karolinum.

Kunský, Josef. 1961. Čeští cestovatelé. Díl druhý. Praha: Orbis.

Latour, Bruno. 1993. We have never been modern. Cambridge, Massachusetts: Harvard University Press.

Loewenstein, Bedřich. 1997. My a ti druzí. Dějiny, psychologie, antropologie. Brno: Doplněk. Martínek, Jiří - Martínek, Miloslav. 1998. Kdo byl kdo. Naši cestovatelé a geografové. Praha: Libri.

Martínek, Jiří. 2008. Geografové v českých zemích 1800-1945 (biografický slovník). Praha: Historický ústav.

Martínek, Jiří. 2017. Geograf a cestovatel Jiří Daneš. Praha: Historický ústav.

Paclt, Čeněk. 1954. Cesty světem. Příhody a zkušenosti na cestách po Americe, Austrálii, Novém Zélandě a jižní Africe. Praha: Orbis.

Pavlíček, Tomáš W. - Tomsová, Petra, spolupráce Blanka Hnulíková a Vlasta Mádlová. 2016. Vybrané fotografie J. V. Daneše z cesty kolem světa. Interpretace a restaurátorské zhodnocení části fotografického fondu. Práce z dějin Akademie věd 8: 1: 44-87.

Todorovová, Jiřina. 2011. Kolem světa. Sbírka fotografií z cest Josefa Kořenského v Náprstkově muzeu asijských, afrických a amerických kultur. Praha: Národní muzeum.

Wittlich, Filip. 2012. Fotografie - přimý svědek?! Fotografický obraz a jeho význam pro historické poznání. Praha: Nakladatelství Lidové noviny.

Život a práce prof. Dra J. V. Daneše. 1880-1928. Life and Work ofJ. V. Daneš. 1928. Praha: Československá společnost zeměpisná. 


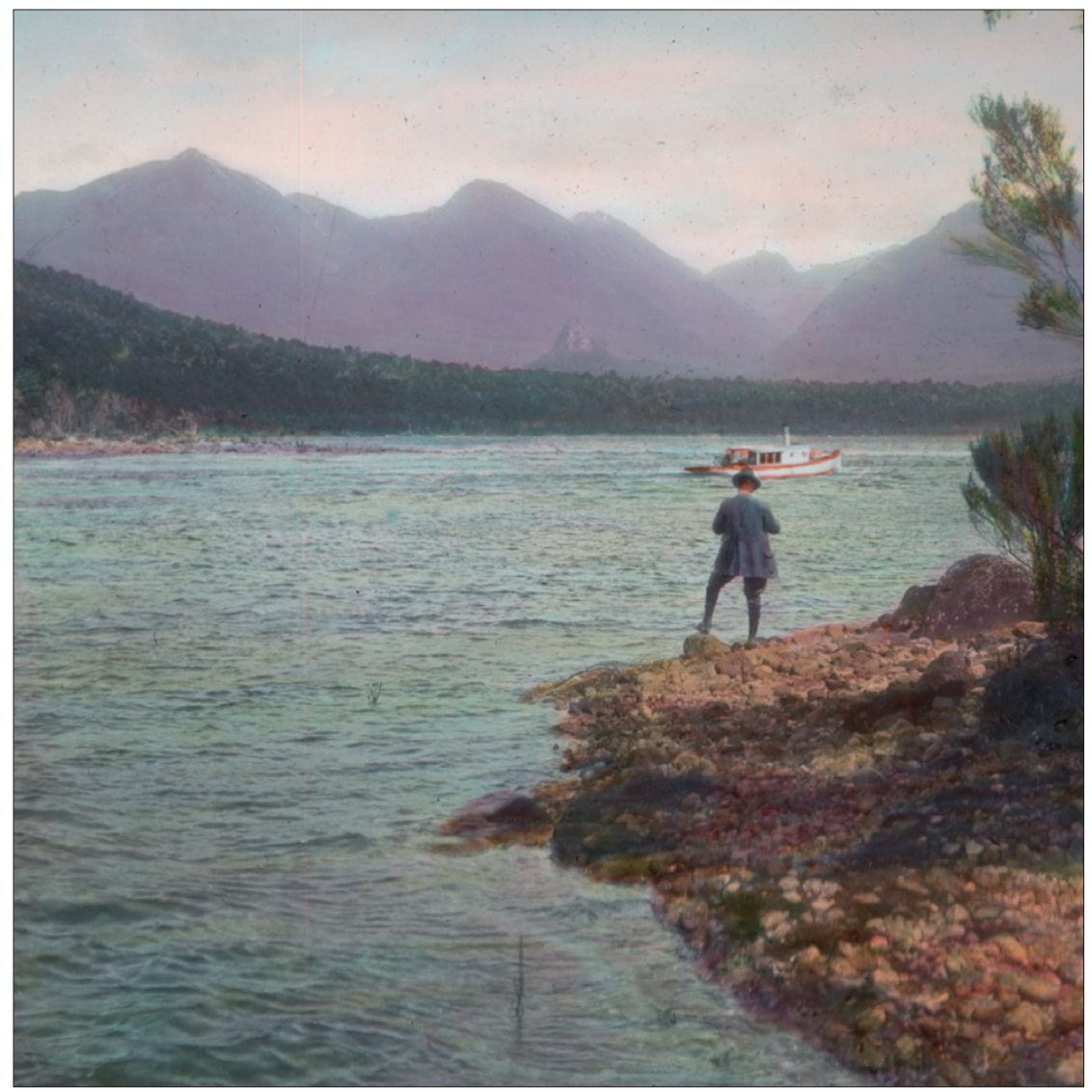

Obr. 1 - Při výtoku řeky Waiau z jezera Manapouri (kolorovaný diapozitiv č. 414/12, $8,5 \times 8,5 \mathrm{~cm})$

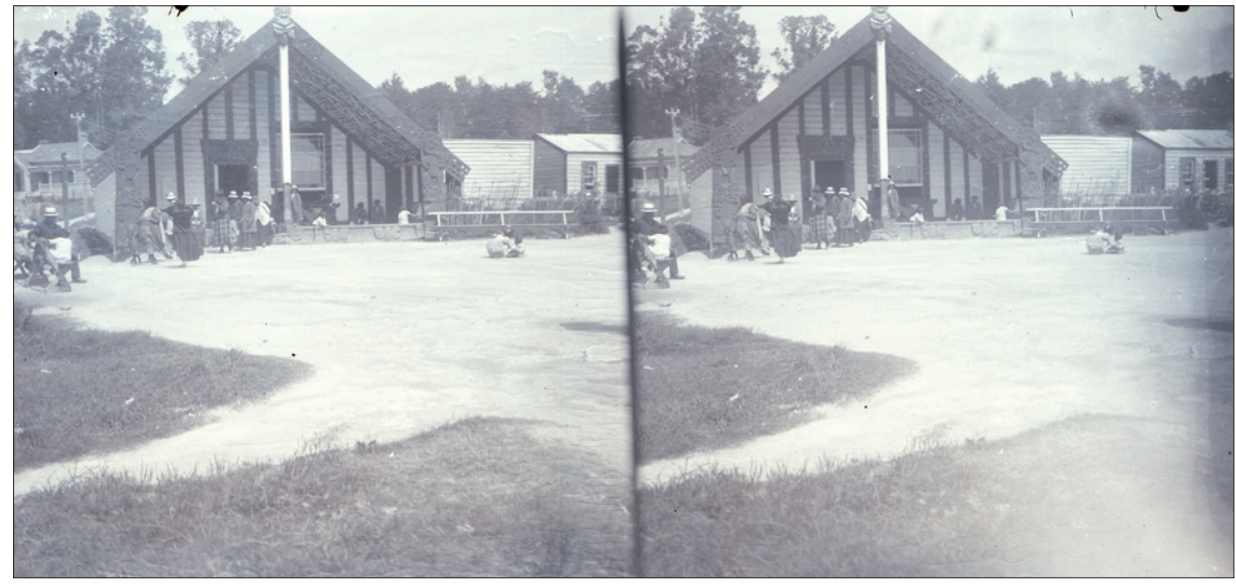

Obr. 2 - Whare v Ohinemutu, jiný záběr (negativ č. 412/60, $9 \times 18$ cm, stereo, poškozeno vodou) 


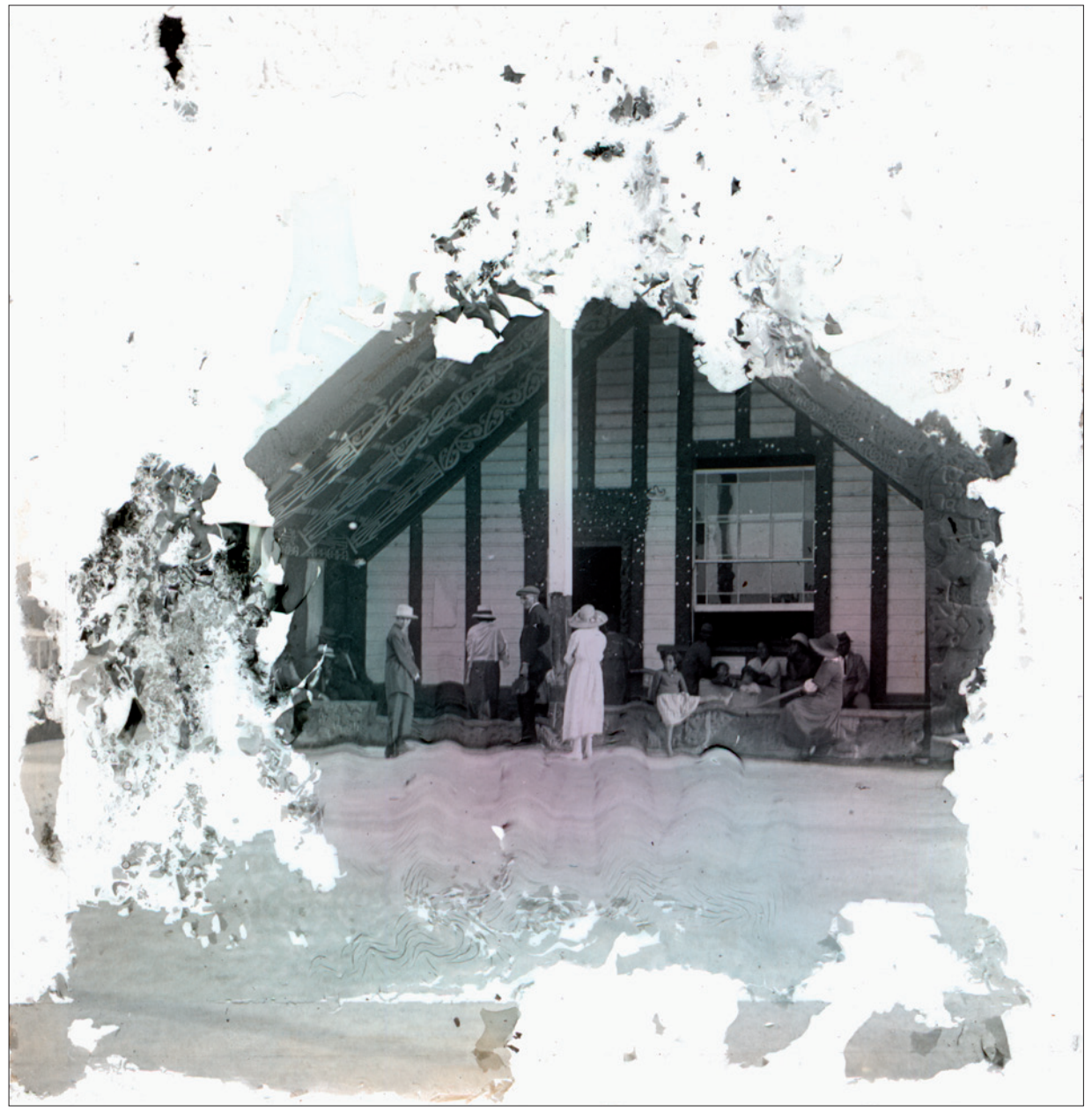

Obr. 3 - Whare v Ohinemutu (původně kolorovaný diapozitiv č. 412/59, 8,5 × 8,5 cm, poškozeno vodou) 